Journal homepage: http://www.journalijar.com
Journal DOI: $10.21474 /$ IJAR01

RESEARCH ARTICLE
INTERNATIONAL JOURNAL

OF ADVANCED RESEARCH

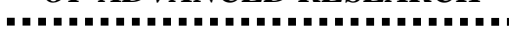

ISSN NO. 2320-5407

\title{
WOMEN OF MAHASWETA DEVI: WALKING THROUGH FIRE?
}

\author{
Dr. Indrani Singh Rai.
}

Associate Professor, Amity School of Languages, Amity University, Chhattisgarh.

\section{Manuscript Info}

Manuscript History:

Received: 15 May 2016

Final Accepted: 19 June 2016

Published Online: July 2016

Key words:

Subaltern, Margin, Elite,

Utilization, Insurgency.

*Corresponding Author

Indrani Singh Rai.

\begin{abstract}
The relentless struggle for endurance of subaltern in elite-society, the intense twinge and trauma of estranged periphery, and the audacity to break the silence and shift towards the core- these traits of Mahasweta Devi's writing were the alluring force to search the interior of marginal psyche, especially two women Sanichari of Rudali and Dhouli of Outcasts: Four Stories. They, though, living on the edges tried to walk on fire to dissent and counter the callous torment of the centre. This paper is a fervent journey with the outcasts to unfurl the history of the human spirit that has been striving for deliverance and bliss from long back still tries to seek life through buoyancy and fortitude.
\end{abstract}

.Copx Right IJAR 2016. All rights reserved...

\section{Introduction:-}

The space between margin and center intensifies the gap between the inhabitants of two poles. It seems, the margin is a part of the whole but stays outside the core. The margin, because of its position, is enforced to comprehend mainstream society as well as its suburbs, and intermittently surge between the two. To understand marginalized folks as well as the practice and upshot of marginalization is centrally crucial when it comes to analyzing social issues because of the fact that people at the margins have a widespread sense of the larger group in which they exist. Mahasweta Devi is a prominent name in the history of modern Indian literature because of her avid vow and anticipation, to her exposure of discrimination and exploitation of the segregated folks. She is a nifty architect to build an ingenious dialect to the callous realities of socio- economical and political exploitation in the present society. Her characters who are living on the edges dare to confront center ignoring consequences. Her women characters dare to break duel bondages, one patriarchy and second, subaltern shackle and to write this alien history, they are found to walk on the fire.

Gayatri Chakraboty Spivak in the essay, "Can the Subaltern Speak?" wrote:

The Subaltern cannot speak. There is no virtue in global laundry lists with woman as a pious. Representation has not withered away. The female intellectual has a circumscribe task which she must not disown with a flourish. (308)

But Mahasweta's women characters focus the subalterns' surging struggle against bare and blatant exploitation. Her novels, dramas and short stories are actually accounts of an obnoxious and autocratic socio-economic system where the excruciating fight is between human being and unbearable hunger and survival, a system which compels the 'have nots' to live in a margin.

Sanichari, the brave warrior of Mahasweta's revolutionary creation Rudali, is historicized: "In Tahad village, ganjus and dushads were in a majority. Sanichari was a ganju by caste. Like other villagers, her life too was lived in desperate poverty." (54) From the beginning, she has to face so many obstacles from social and economical levels because she tries to oppose and change the static, ceaseless tradition of society. She is a poor, low-caste agricultural labour for whom nothing has ever come easy. Every loss she suffers is because of the gloomy poverty and the knotted. She is 'rudali' who is used by rich pole 'to mourn' on death of elite because it is a characteristic of the malik-mahajan's social class. When there is a death in their families, they have to hire 'rudalis' to mourn for them so 
as to add to their prestige since this market exists, the outcast and marginalized can supply their skilled labour to service it. The rudalis, the worn out bond labourers, sell but their howls and some of them have been seduced, ruined and thrown into the whores' quarters by the same malik-mahajans. In this way, upper class takes pride and pleasure of place in the intricate feat of a rich man's death ritual. All 'rudalis' are disheartened and displaced and have been destined to be silent and loner in ancestral hierarchy.

Mahasweta enables these subalterns to resort to 'strategic essentialism', to borrow the concept of Gayatri Spivak, a sort of temporary solidarity, an 'essentialist' position in order to be able to act. Anjum Katyal comments:

I see Rudali...as activist fiction. It sets out to support the process of struggle she writes about-by enlightening, educating, celebrating, reaffirming and inspiring. It participates in the struggle by attacking, through accusation and exposure, the exploitative system the struggle targets and the individuals through whom this system functions. Fiction is honed into a weapon by being presented as its apparent opposite, reportage. Just as Dulan's work in Rudali is consciousness-raising, Rudali's work is conscientizing. (27)

The essential resilience in Sanichari finds its path she emerges as confident, in control and empowered. She confronts her social superiors audaciously. She has proved that her howl of grief has changed into a howl of victory, in other way it is the unyielding elation of the 'essentialists'. When 'She' is denied her right to live, she fights back. Rudali unfolds the story of people like Sanichari, who forever search for a real space within the mainstream where they can 'belong' actually with genuine shelter and harmony.

Dhouli is a short story taken from Outcast: Four Stories by Mahasweta. The story is a keen witness of the vengeance and dissent of a tribal 'dushad' woman who is a prey of the incessant class, caste and gender exploitation that makes her life a inexorable struggle for survival. The dushad tribe is treated as untouchable by the upper caste masters of the village. They are prohibited to lead their lives at their own will. "What does Dhouli expect? She's a dushad, an untouchable; did she expect a house or land?" (2) Dhouli got married in her early childhood with the help from the Misras, the land lord of the village and became bonded labour eternally. The life was accepted by the helpless widow. She knew that wearing coarse, slaving on the mahajan's farm or the jotedar's fields or doing road construction work, hardly managing one square meal at the end of the day were her destiny. Physical labour can be accepted by a woman but when she is psychologically disillusioned and when she becomes a mother due to deceive, it is hard to accept. When Misrilal tried to molest her, Dhouli replied, "What can I do? Nothing. Deotas like you always get what you want! Go ahead, take me, dishonour me." (10) It's really ironical that a high caste man can involve physically with a tribal lady secretly but she is accepted as untouchable by himself openly.

Any sensitive soul can measure up the anguish and the privation suffered by outcastes like Dhouli for centuries. She argues for a place in the society because it is her right to protest against social discrimination. Dhouli, the mother, after being overlooked and abandoned by her so called lover, decides to be a prostitute freely to lead her and her son's livelihood. She understands "How simple to sell one's body in a loveless exchange for salt, corn, maroa. If she had known it was that easy, she would have done it much earlier. Her son too would have been well fed, healthy." (28) Her protest is the release of human soul from all kinds of oppression and exploitation. She proves that even the lowliest human being, who has practically been denied a place among the inhabitants of main stream life and measured to be a weight of the society, can lead a life by her will. When Misrilal accuses her for becoming a kept woman and asks why she has still not committed suicide, Dhouli dissents, "I tried to kill myself. But then I thought why should I? You can get married, run a shop, see movies with your wife, and I have to kill myself? Why? Why? Why?" (31)

Dhouli is the messenger of so many Dhoulis who offers a judicious discourse on how people live under the oppression. The marginalized psyche uncovers the existential anger of the unspoken dreamer. She is an archetype of how a tribal low caste woman lives in cosseted self in the same society where elite lives. The society is desired to be sensitized to the malice of some of its traditions which dehumanize social taboos. The frail, poor and pathetic lowbirth people like Dhouli and Sanichari are treated as distant and occupied objects. In this social structure, things are decided for both by the patriarchal ideology of an ancient culture which also cultivates the hierarchal snobbishness and hostility of the 'high' towards the 'low'. This arrogance must be protested and Dhoulis should be protected and given their respective honour. 


\section{Conclusion:-}

Now the question is how many people have ever sought to perceive the abject plight of outcasts? Have they ever listened to the unhappy pray of pariah? Perhaps very few have felt with the recluses, recognize the core of their susceptibility, agony and protest to find a survival in the mainstream. The relentless struggle for endurance of Dhouli and Sanichari, the subaltern women who are intimidated to become prostitutes intensifies a trauma to accept that the pariahs in reality are astounded victims strained by the will of privileged. Sharing the same periphery with others, why a group is so distant? Dhouli or Sanichari's voyage is a fervent journey to unfurl the history of the human spirit that has been striving for deliverance and bliss from long back still tries to seek life through resilience and fortitude. Walking through fire is to be clogged because footprints are more enviable than vestiges.

\section{References:-}

1. Devi, Mahasweta. 1990. Bashai Tudu. Trans. Samik Bandopadhyay and Gayatri Chakravorty Spivak. Calcutta: Thema.

2. Rudali: From Fiction to Performance. 1999. Trans. Anjum Katyal. Calcutta: Seagull Books.

3. Outcast: Four Stories. 2002. tr. by Sarmistha Dutta Gupta. Calcutta: Seagull Books, 2002.

4. Guha, Ranajit. 1983. "The Prose of Counter-Insurgency," Subaltern Studies II. Ed. Guha. Delhi: Sahitya Akadamy. 